\title{
Tumor $\beta$-catenin expression is associated with immune evasion in non-small cell lung cancer with high tumor mutation burden
}

\author{
SATOSHI MUTO $^{1}$, YUKI OZAKI ${ }^{1}$, HIKARU YAMAGUCHI ${ }^{1}$, HAYATO MINE $^{1}$, HIRONORI TAKAGI $^{1}$, \\ MASAYUKI WATANABE ${ }^{1}$, TAKUYA INOUE ${ }^{1}$, TAKUMI YAMAURA ${ }^{1}$, MITSURO FUKUHARA ${ }^{1}$, \\ NAOYUKI OKABE ${ }^{1}$, YUKI MATSUMURA ${ }^{1}$, TAKEO HASEGAWA ${ }^{1}$, JUN OSUGI ${ }^{1}$, \\ MIKA HOSHINO ${ }^{1}$, MITSUNORI HIGUCHI ${ }^{1}$, YUTAKA SHIO ${ }^{1}$, HIDEAKI NANAMIYA ${ }^{2}$, \\ JUN-ICHI IMAI $^{2}$, TAKAO ISOGAI ${ }^{2}$, SHINYA WATANABE ${ }^{2}$ and HIROYUKI SUZUKI ${ }^{1}$ \\ ${ }^{1}$ Department of Chest Surgery; ${ }^{2}$ Translational Research Center, \\ Fukushima Medical University School of Medicine, Fukushima 960-1295, Japan
}

Received July 22, 2020; Accepted December 17, 2020

DOI: $10.3892 / \mathrm{ol} .2021 .12464$

\begin{abstract}
. $\beta$-catenin expression by tumor cells suppressed dendritic cell recruitment to the tumor microenvironment in a melanoma model, resulting in fewer tumor-infiltrating lymphocytes. Immunohistochemistry was used in the present study to examine the association between the expression of $\beta$-catenin and tumor infiltrating lymphocytes and $\mathrm{CD} 11 \mathrm{c}^{+}$cells in 122 patients with non-small cell lung cancer (NSCLC), who underwent radical surgery. $\beta$-catenin was positive in $24 \%$ of NSCLC tumors compared with $59 \%$ of squamous cell carcinomas and $11 \%$ of adenocarcinomas. There was no significant association between the expression of $\beta$-catenin and the frequency of $\mathrm{CD}^{+}$cell infiltration into tumor tissues, including the stroma. Conversely, the infiltration of $\mathrm{CD}^{+}$cells into tumor nests was significantly lower in $\beta$-catenin-positive cases compared with that in negative $\beta$-catenin cases. Similarly, CD11 $\mathrm{c}^{+}$cell infiltration was significantly lower in the $\beta$-catenin-positive group. The $\beta$-catenin-positive group had shorter overall survival and recurrence-free survival times compared with that in the negative group. Furthermore, $\beta$-catenin-positive NSCLC had a high tumor mutation burden, but tended to have a low expression of programmed death-ligand 1 . In conclusion, the expression of $\beta$-catenin in NSCLC was negatively associated with CD11c ${ }^{+}$cells and cytotoxic $\mathrm{T}$ cell infiltration at the tumor site and had a tendency towards a poor prognosis.
\end{abstract}

Correspondence to: Dr Satoshi Muto and Dr Hiroyuki Suzuki, Department of Chest Surgery, Fukushima Medical University School of Medicine, 1 Hikarigaoka, Fukushima 960-1295, Japan

E-mail: smutoo@fmu.ac.jp

E-mail: hiro@fmu.ac.jp

Key words: cancer immunotherapy, tumor immune evasion, beta-catenin, tumor infiltrating lymphocytes, non-small cell lung cancer

\section{Introduction}

Immunotherapy in cancer, particularly non-small cell lung cancer (NSCLC), has undergone remarkable advances in recent years. Immune checkpoints including programmed death (PD)-1/L1 are involved in immune escape in patients with cancer. Immune checkpoint inhibitors are effective in certain proportions of patients and are now a standard primary treatment for NSCLC $(1,2)$. However, the effect of a single agent is limited to $20 \%$ of patients. Therefore, basic research studies have been initiated to clarify the initial tolerance and acquired resistance to immune checkpoint inhibitors and various combination therapies in clinical use. The combination of immune checkpoint inhibitors with chemotherapy has already been added to the standard treatment (3-5), and numerous other clinical trials, including combination therapy with other immunotherapy agents, are in progress.

The PD-L1 tumor proportion score (TPS) have been used as a predictive biomarker for immune checkpoint inhibitors (6); however, this is not adequate as some patients respond to immune checkpoint inhibitors, even though the PD-L1 TPS of their tumor is $0 \%$ and vice versa. In addition, the tumor mutation burden (TMB) (7) and tumor infiltrating lymphocytes (TILs) (8) were previously used to determine the effects of immune checkpoint inhibitors. TMB reflects the number of neo-antigens in a tumor, and therefore, in cancer with high TMB, immune checkpoint inhibitors are likely to have a positive effect (9). Conversely, PD-L1 TPS is thought to reflect the production of interferon- $\gamma($ IFN- $\gamma$ ) in the tumor microenvironment (10), as well as being a biomarker for the tumor expression of PD-L1. It reflects the cytolytic activity of cytotoxic T cells and natural killer T cells in the tumor microenvironment. The cancer immune cycle starts with neo-antigen expression (TMB) followed by the infiltration of lymphocytes into the tumor (TILs) and finally cytolytic activity (PD-L1 expression). The associations of TMB and PD-L1 expression with antitumor immune responses are well-known, but factors associated with TILs are poorly understood. However, a high number of TILs in NSCLC is a good prognostic factor (11). 
Spranger et al $(12,13)$ reported that tumors expressing $\beta$-catenin in a melanoma model suppressed dendritic cell recruitment via decreased chemokine production, which consequently decreased the numbers of TILs. $\beta$-catenin is involved in cell proliferation (14) and the epithelial-mesenchymal transition (EMT) of cancer cells (15). $\beta$-catenin expression was also reported to be associated with a poor prognosis, even in NSCLC (16), and resistance to chemotherapy (17) or tyrosine kinase inhibitors (18). Spranger et al (12) suggested that $\beta$-catenin might also be involved in tumor immune evasion, thereby promoting the development of cancer.

However, whether $\beta$-catenin is involved in tumor immune escape mechanisms in lung cancer is unclear. Although NSCLC cases with abnormal $\beta$-catenin expression had low numbers of TILs (19), it was unclear whether this was associated with dendritic cells. Therefore, the present study investigated the association between $\beta$-catenin expression, TILs, and $\mathrm{CD}_{11} \mathrm{c}^{+}$cells in NSCLC. CD11c is a marker of mononuclear phagocytes (20) and is expressed on antigen presenting cells (APCs) (21). CD11c, also known as integrin $\alpha \mathrm{X}$, is a transmembrane protein. CD11c mediates phagocytosis (22) and binds to cell adhesion molecules (23-25), components of the bacterial wall $(26)$, complement proteins $(22,27)$ and matrix proteins $(28,29)$. TMB and PD-L1 TPS were examined for evaluable cases and their association with $\beta$-catenin expression was clarified. Furthermore, the association between overall survival and relapse-free survival was examined.

\section{Materials and methods}

Patients. A total of 122 patients with NSCLC, who underwent complete resection between January 2013 and December 2015 at the Hospital of Fukushima Medical University, were enrolled. No chemotherapy or immunotherapy was administered before surgery. Disease staging was evaluated according to the International Staging System for Lung Tumors, 7 th edition (30).

Immunohistochemistry. Paraffin-embedded NSCLC specimens were cut into 3- $\mu \mathrm{m}$ microtome sections. The sections were deparaffinized in xylene and dehydrated in a desending alcohol series (99\% for $2 \mathrm{~min}, 90 \%$ for $1 \mathrm{~min}$, then $70 \%$ for $1 \mathrm{~min}$ ). Endogenous peroxidase activity was blocked by a 20-min incubation with $0.3 \%$ (v/v) solution of hydrogen peroxidase (Wako Pure Chemical Industries Ltd.) in 100\% methanol. Following incubation with 5\% skimmed milk in PBS for 30 min at room temperature, the sections were incubated overnight at $4^{\circ} \mathrm{C}$ with primary monoclonal antibodies against $\beta$-catenin (1:100; cat. no. UMAB15; OriGene Technologies, Inc.), CD8 (1:50; cat. no. C8/144B; Agilent Technologies, Inc.), or CD11c (1:200; cat. no. 2F1C10; ProteinTech Group, Inc.). The primary antibody was then detected using biotinylated secondary anti-mouse IgG (1:400; cat. no. E0413) or anti-rabbit IgG antibodies (1:400; cat. no. E0431) (both from Dako; Agilent Technologies, Inc.) using the avidin-biotin complex method. The sections were counterstained with Mayer's haematoxylin (Muto Pure Chemicals Co., Ltd.), dehydrated using 99\% alcohol for three min, and mounted on glass slides.

For each specimen, micrographs of high-power fields (HPF; magnification, $\mathrm{x} 400$ ) were captured using a light microscope (IX73; Olympus Corporation) with a CCD camera (DP73; Olympus Corporation). Then, micrographs were analyzed by two investigators without knowledge on the corresponding clinicopathological data. Specimens containing tumor cells with only membranous staining were defined as negative (normal) $\beta$-catenin expression. Specimens containing tumor cells with cytoplasmic staining were defined as positive (abnormal) $\beta$-catenin expression. Evaluation of tumor infiltrating $\mathrm{CD}^{+}$cells and $\mathrm{CD} 11 \mathrm{c}^{+}$cells was performed according to the visual estimation of these cells in each visual field. The number of $\mathrm{CD}^{+}$cells was evaluated into one of three groups: Small $(<30 \%)$, medium $(30-60 \%)$ and large $(>60 \%)$, as previously reported (31). Furthermore, $\mathrm{CD}^{+}$and $\mathrm{CD} 11 \mathrm{c}^{+}$ cell infiltrations into tumor nests were evaluated as positive or negative.

PD-L1 TPS was evaluated in 68 patients using a PD-L1 IHC 22C3 pharmDx immunohistochemistry assay on the Dako Autostainer Link 48 at SRL, Inc. PD-L1 TPS was defined as the percentage of viable tumor cells with partial or complete membrane staining (32). These 68 patients were randomly selected in clinical practice from a total of 122 patients.

Sequencing analysis. Whole exome sequencing was conducted in accordance with the Ethical Guidelines for Human Genome and Genetic Analysis Research. In 122 patients with NSCLC, whole exome sequencing of 79 tumors and paired normal samples was performed using Ion Amplise Exome technology and the Ion Proto platform (Thermo Fisher Scientific, Inc.). Tumor volume was insufficient for the analysis of the remaining 43 patients. The obtained DNA sequences were aligned to hg19 of the human genome. The mean coverage depth was $123 \mathrm{X}$ and $90.4 \%$ of target bases had a coverage of 20X. Sequence variants in the tumors were named using Ion Reporter v5.0 (Thermo Fisher Scientific, Inc.) and CLC Genomics Workbench v8.0 software (Qiagen, Inc.), and the number of non-synonymous coding variants was counted. The obtained value was designated the TMB. In addition, gene mutation analysis was conducted for catenin $\beta 1$ (CTNNB1) and three associated genes: APC regulator of WNT signaling pathway $(A P C)$, axin $1(A X I N 1)$, and transcription factor 7 (TCF7).

Flow cytometry. Tumor infiltrating $\mathrm{CD} 45^{+}$cells in two patients with NSCLC were analyzed using flow cytometry. There was one patient with squamous cell carcinoma and the other had adenocarcinoma of the lung. Tumor specimens from both patients were $\beta$-catenin negative by immunohistochemistry. $\mathrm{CD}^{+}$and $\mathrm{CD}^{+} 1 \mathrm{c}^{+}$cell infiltrations into tumor nests were positive in both cases. A 7-mm square of tissue was obtained from each patient's tumor at surgical resection. The tissue was dissociated into a single-cell suspension using a gentleMACS Dissociator (Miltenyi Biotec GmBH). Blood cells were separated and collected by CD45 MicroBeads and autoMACS separator (Miltenyi Biotec) and then stained with the following antibodies: PE anti-human CD11c (1:20; cat. no. 301605; BioLegend, Inc.), PE/Cy7 anti-human HLA-DR (1:20; cat. no. 307615; BioLegend, Inc.), PerCP/Cy5.5 anti-human CD163 (1:20; cat. no. 326511; BioLegend, Inc.), APC/Cy7 anti-human CD14 (1:20; cat. no. 301819; BioLegend, Inc.), APC anti-human CD86 (1:20; cat. no. 305411; BioLegend, Inc.), and 
Table I. Patient characteristics $(n=122)$.

\begin{tabular}{|c|c|c|c|}
\hline \multirow[b]{2}{*}{ Characteristics } & \multicolumn{2}{|c|}{$\beta$-catenin } & \multirow[b]{2}{*}{ P-value } \\
\hline & Positive & Negative & \\
\hline Total, n (\%) & $29(24)$ & $93(76)$ & \\
\hline Age, years & $69.6 \pm 10.3$ & $68.9 \pm 9.4$ & 0.7469 \\
\hline Sex, n (\%) & & & 0.2643 \\
\hline Male & $22(76)$ & $59(63)$ & \\
\hline Female & 7 (24) & $34(37)$ & \\
\hline Smoking, pack years & $47.3 \pm 36.9$ & $27.0 \pm 29.5$ & 0.0098 \\
\hline p-Stage, n (\%) & & & 0.0785 \\
\hline 1 & $18(62)$ & $75(81)$ & \\
\hline 2 & $5(17)$ & $11(12)$ & \\
\hline 3 & $6(20)$ & $7(8)$ & \\
\hline Tumor size, mm & $37 \pm 21$ & $29 \pm 16$ & 0.0472 \\
\hline Histology, n (\%) & & & $<0.0001$ \\
\hline Ad & $10(34)$ & $80(86)$ & \\
\hline $\mathrm{Sq}$ & $19(66)$ & $13(14)$ & \\
\hline
\end{tabular}

Data show component size, number or mean \pm standard deviation. Ad; adenocarcinoma, Sq; squamous cell carcinoma.

FITC anti-human CD20 (1:20; cat. no. 130-113-373; Miltenyi Biotec GmBH). Samples were acquired with a FACSCanto II (BD Biosciences) and analysed using FlowJo software v10.0 (FlowJo LLC). The samples were gated on single cells, then the lymphocytes and monocytes were selected and analyzed.

Statistical analysis. T-test, Fisher's exact test, $\chi^{2}$ test, and log-rank test were performed using GraphPad Prism software v8.4.3 (GraphPad Software, Inc.). Continuous variables are presented as the mean \pm SEM. $\mathrm{P}<0.05$ was considered to indicate a statistically significant difference. Survival curves were drawn using the Kaplan-Meier method, and differences in survival were evaluated using the log-rank test. The Cox proportional regression model using the forward stepwise likelihood ratio method was performed to select prognostic factors of survival using SPSS software v27 (IBM Corp.).

\section{Results}

$\beta$-catenin expression and patient characteristics. Patient characteristics are presented in Table I. Tumor $\beta$-catenin expression was positive in 29 patients $(24 \%)$. The $\beta$-catenin-positive group had higher smoking status and larger tumor size compared with the $\beta$-catenin-negative group. $\beta$-catenin was more commonly found in squamous cell carcinoma $(16 \%)$ compared with adenocarcinoma $(8 \%)$. There was no difference in age, sex, or pathological stage between $\beta$-catenin-positive and -negative groups.

$\beta$-catenin expression in tumors, and tumor infiltrating lymphocytes and $C D 11 c^{+}$cells. $\beta$-catenin positive NSCLC patients had low $\mathrm{CD}^{+}$and $\mathrm{CD} 11 \mathrm{c}^{+}$cell infiltration into tumors (Fig. 1). There were two types of tumor infiltrating lympho-
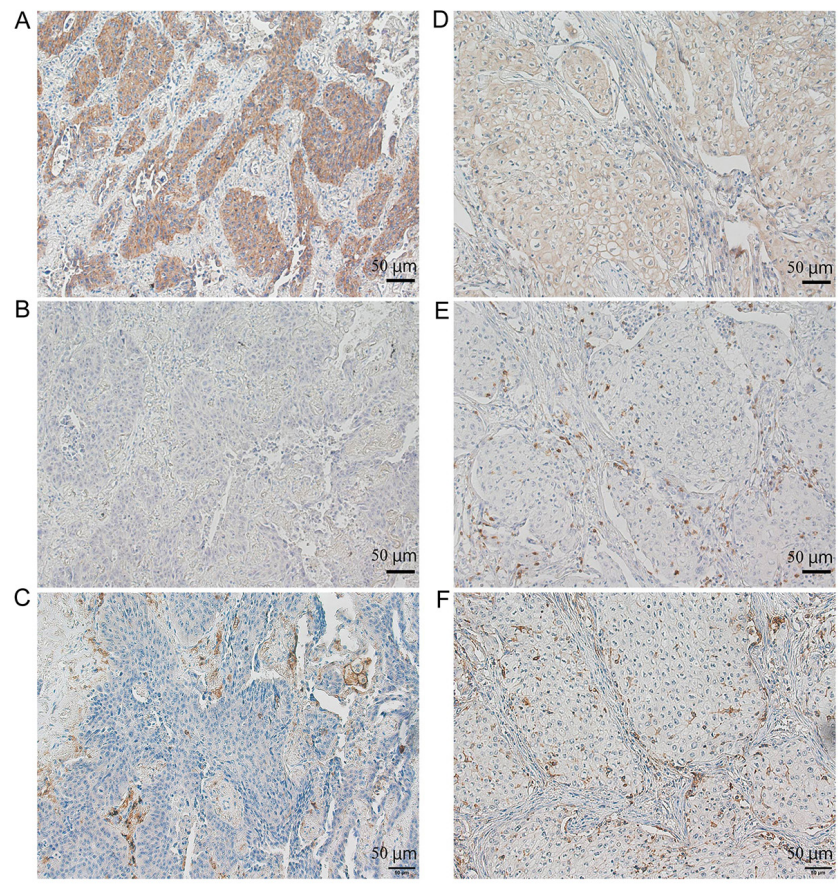

Figure 1. Representative immunohistochemistry images of NSCLC (A-C) $\beta$-catenin-positive and (D-F) $\beta$-catenin-negative NSCLC. Staining for (A and D) $\beta$-catenin, (B and $\mathrm{E}$ ) $\mathrm{CD} 8$, and (C and F) CD11c. In $\beta$-catenin-positive NSCLC, lower numbers of CD8 and CD11c positive cells were present compared with $\beta$-catenin-negative NSCLC. NSCLC, non-small cell lung cancer.

cytes: Those present in the stroma; and those that directly infiltrated into the tumor nests (Fig. 1E). $\beta$-catenin expression was associated with $\mathrm{CD}^{+}$and $\mathrm{CD} 11 \mathrm{c}^{+}$cell infiltration into tumor nests regardless of the total number of $\mathrm{CD}^{+}$cells in 
Table II. Number of patients associated with $\beta$-catenin expression, tumor-infiltrating CD8 ${ }^{+}$cells, and tumor infiltrating CD11c cells $(\mathrm{n}=122)$.

\begin{tabular}{|c|c|c|c|}
\hline \multirow[b]{2}{*}{ Characteristics } & \multicolumn{2}{|c|}{$\beta$-catenin } & \multirow[b]{2}{*}{ P-value } \\
\hline & Positive & Negative & \\
\hline $\mathrm{CD} 8^{+}$cell infiltration into tumor nests, $\mathrm{n}(\%)$ & $10(8)$ & $80(66)$ & $<0.0001$ \\
\hline+ & $19(16)$ & $13(11)$ & \\
\hline- & & & \\
\hline 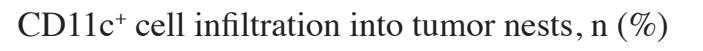 & & & 0.0788 \\
\hline+ & $15(12)$ & $65(53)$ & \\
\hline- & $14(11)$ & $28(23)$ & \\
\hline Total number of $\mathrm{CD} 8^{+}$cells in tumor sites, $\mathrm{n}(\%)$ & & & 0.8781 \\
\hline Large & $9(7)$ & $30(25)$ & \\
\hline Medium & $18(15)$ & $54(44)$ & \\
\hline Small & $2(2)$ & $9(7)$ & \\
\hline
\end{tabular}

A

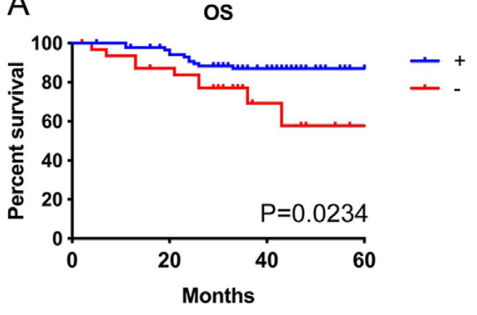

C

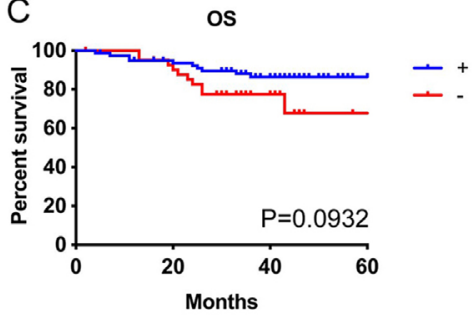

$E$

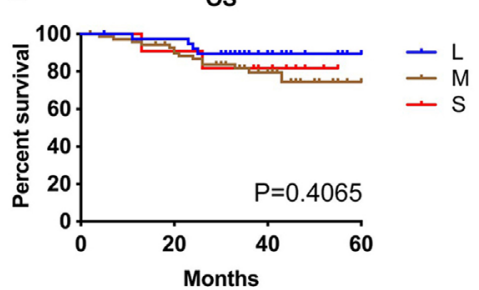

B

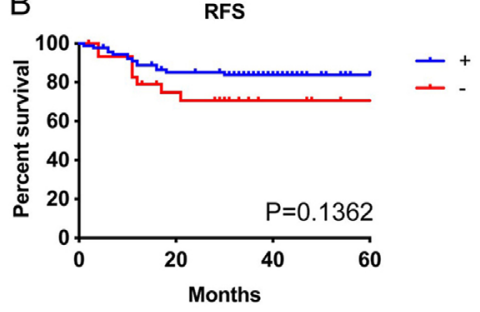

$\mathrm{D}$

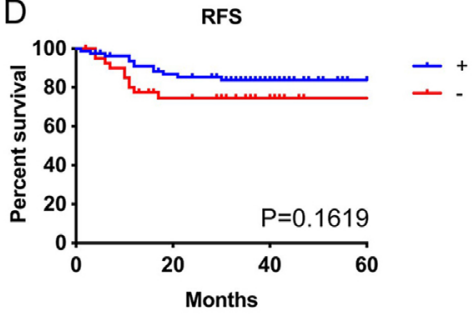

F

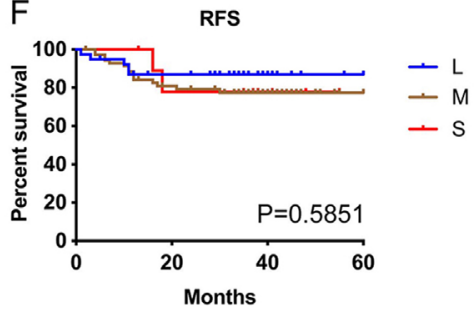

Figure 2. Survival and tumor infiltrating immune cells. Analysis between OS and RFS, and (A and B) tumor epithelial infiltration of CD8 ${ }^{+}$lymphocytes, $(\mathrm{C}$ and $\mathrm{D}) \mathrm{CD} 11 \mathrm{c}^{+}$cells, and (E and F) total number of $\mathrm{CD}^{+}$cells in the tumor tissues, including the stroma, respectively. Infiltration into the tumor epithelium, but not numbers of tumor infiltrating lymphocytes, was associated with prognosis. Infiltration of CD11 $\mathrm{c}^{+}$cells into the tumor epithelium tended to be similar to that of CD8 ${ }^{+}$lymphocytes. +, cases with tumor epithelial infiltration of cells; -, cases without tumor epithelial infiltration of cells; L, large; M, medium; S, small; OS, overall survival; RFS, relapse-free survival.

the tumor sites (Table II). There was a significant association between $\mathrm{CD}^{+}$and $\mathrm{CD} 11 \mathrm{c}^{+}$cell infiltration $(\mathrm{P}<0.0001)$. The infiltrations of $\mathrm{CD}^{+}$and $\mathrm{CD} 11 \mathrm{c}^{+}$cells into tumor nests were good prognostic factors. The group without $\mathrm{CD}^{+}$cell infiltration into tumor nests had a significantly shorter overall survival time $(\mathrm{P}=0.0234)$ and tended to have a shorter recurrence-free survival time compared with the $\mathrm{CD}^{+}$cell infiltration group $(\mathrm{P}=0.1362$; Fig. $2 \mathrm{~A}$ and $\mathrm{B})$. The group without $\mathrm{CD} 11 \mathrm{c}^{+}$cell infiltration into the tumor nests also tended to have short overall survival time $(\mathrm{P}=0.0932)$ and recurrence-free survival time ( $\mathrm{P}=0.1619$; Fig. $2 \mathrm{C}$ and $\mathrm{D})$. Conversely, the total number of $\mathrm{CD}^{+}$cells in tumor sites did not have a clear association with overall survival $(\mathrm{P}=0.4065)$ or recurrence-free survival $(\mathrm{P}=0.5851$; Fig. $2 \mathrm{E}$ and $\mathrm{F})$. The median overall and recurrence-free survival was not reached in all groups. NSCLC with $\beta$-catenin expression tended to have short overall survival 
Table III. Univariate and Cox regression multivariable stepwise procedure of overall survival.

\begin{tabular}{|c|c|c|c|c|c|c|c|}
\hline \multirow[b]{2}{*}{ Characteristics } & \multirow[b]{2}{*}{ Number } & \multicolumn{3}{|c|}{ Univariate analysis } & \multicolumn{3}{|c|}{ Multivariate analysis } \\
\hline & & HR & $95 \% \mathrm{CI}$ & P-value & HR & $95 \% \mathrm{CI}$ & P-value \\
\hline Age ( $<69$ years) & 56 & 0.925 & $0.383-2.232$ & 0.862 & & & \\
\hline Sex (female) & 41 & 0.297 & $0.087-1.016$ & 0.053 & 0.289 & $0.081-1.030$ & 0.055 \\
\hline Smoking $(<32.5)$ & 61 & 0.467 & $0.186-1.171$ & 0.104 & & & \\
\hline p-Stage (1) & 93 & 0.282 & $0.117-0.679$ & 0.005 & & & \\
\hline Tumor size $(<28 \mathrm{~mm})$ & 59 & 0.108 & $0.025-0.467$ & 0.003 & 0.121 & $0.028-0.522$ & 0.005 \\
\hline Histology (Ad) & 90 & 0.324 & $0.134-0.786$ & 0.013 & & & \\
\hline$\beta$-catenin (-) & 93 & 0.229 & $0.095-0.551$ & 0.001 & 0.264 & $0.109-0.640$ & 0.001 \\
\hline
\end{tabular}

HR, hazard ratio; CI, confidence interval; Ad, adenocarcinoma.

Table IV. Univariate and Cox regression multivariable stepwise procedure of recurrence-free survival.

\begin{tabular}{|c|c|c|c|c|c|c|c|}
\hline \multirow[b]{2}{*}{ Characteristics } & \multirow[b]{2}{*}{ Number } & \multicolumn{3}{|c|}{ Univariate analysis } & \multicolumn{3}{|c|}{ Multivariate analysis } \\
\hline & & HR & $95 \% \mathrm{CI}$ & P-value & HR & $95 \% \mathrm{CI}$ & P-value \\
\hline Age ( $<69$ years) & 56 & 0.933 & $0.403-2.160$ & 0.872 & & & \\
\hline Sex (female) & 41 & 0.871 & $0.355-2.137$ & 0.763 & & & \\
\hline Smoking $(<32.5)$ & 61 & 0.633 & $0.270-1.479$ & 0.291 & & & \\
\hline p-Stage (1) & 93 & 0.127 & $0.053-0.303$ & $<0.001$ & 0.204 & $0.081-0.513$ & 0.001 \\
\hline Tumor size $(<28 \mathrm{~mm})$ & 59 & 0.086 & $0.020-0.369$ & 0.001 & 0.132 & $0.028-0.608$ & 0.009 \\
\hline Histology (Ad) & 90 & 1.543 & $0.522-4.566$ & 0.433 & 3.460 & $1.149-10.42$ & 0.027 \\
\hline$\beta$-catenin (-) & 93 & 0.443 & $0.184-1.063$ & 0.068 & & & \\
\hline
\end{tabular}

HR, hazard ratio; CI, confidence interval; Ad, adenocarcinoma.
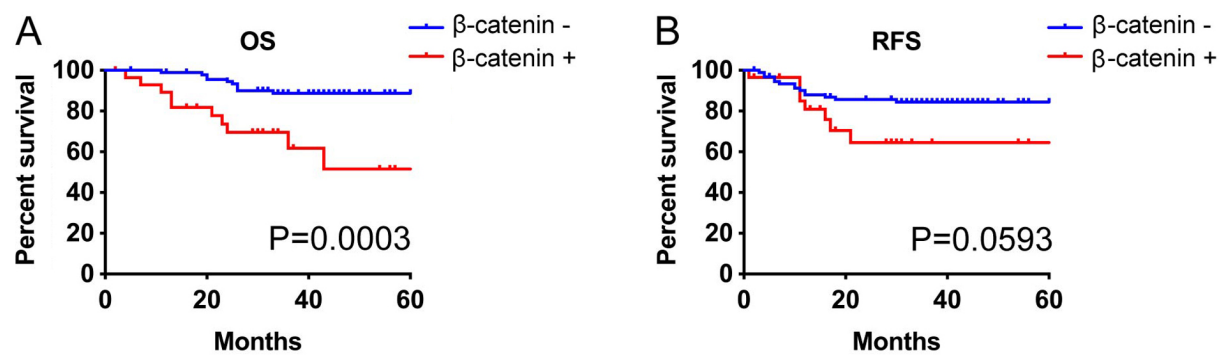

Figure 3. Impact of $\beta$-catenin on prognosis. In $\beta$-catenin-positive NSCLC, (A) the OS was predominantly worse and (B) the RFS tended to be worse. OS, overall survival; RFS, relapse-free survival.

$(\mathrm{P}=0.0003)$ and recurrence-free survival $(\mathrm{P}=0.0593$; Fig. 3$)$ Multivariate analysis indicated that tumor size, $\beta$-catenin, and sex were poor prognosis factors for overall survival although tumor size, histology, and pathological stage were associated with recurrence-free survival (Tables III and IV).

Subsets of tumor infiltrating $C D 11 c^{+}$cells. Flow cytometry revealed that most tumor infiltrating $\mathrm{CD} 45^{+}$cells were HLA-DR positive. Numerous CD11 ${ }^{+}$cells were CD163 positive and CD20 negative. The $\mathrm{CD} 11 \mathrm{c}^{+}$subset also contained cells that were positive and negative for CD14 and CD86 (Fig. S1).

Association of $\beta$-catenin expression with tumor mutation burden and PD-L1 expression. The median TMB was 142 (range, $32-502 ; n=17$ ) in the $\beta$-catenin-positive group and 53 (range, $10-453 ; n=62$ ) in the $\beta$-catenin-negative group. NSCLC-expressing $\beta$-catenin had a significantly higher TMB than non- $\beta$-catenin-expressing lung cancer (Fig. 4A). Conversely, NSCLC-expressing $\beta$-catenin tended to have a 

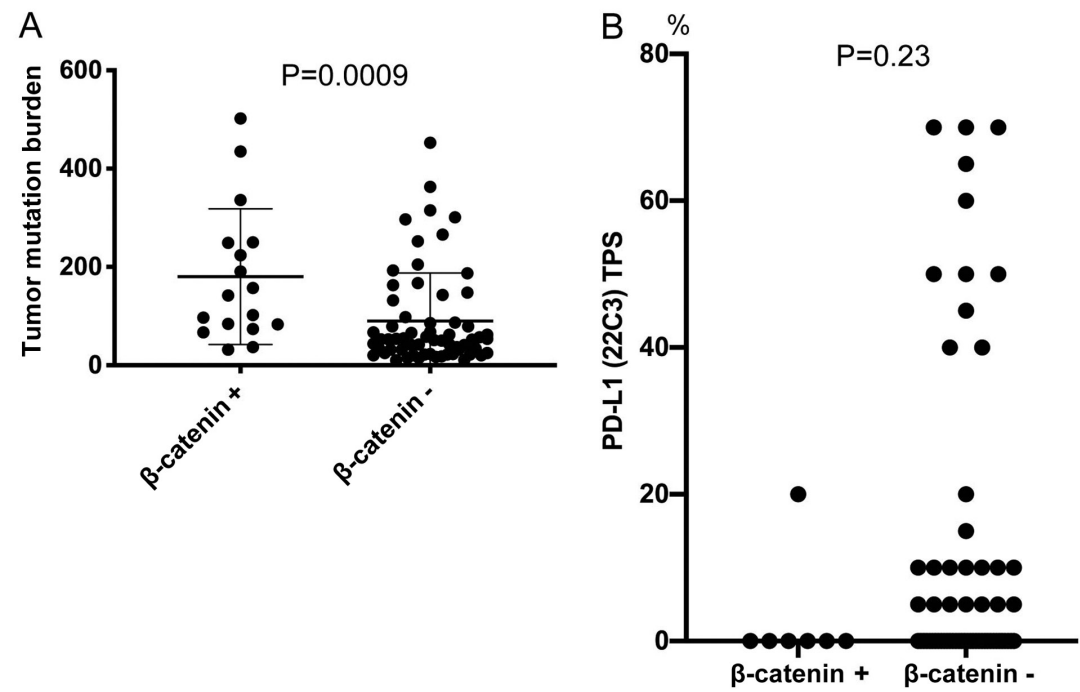

Figure 4. Association between $\beta$-catenin expression and TMB and PD-L1. (A) $\beta$-catenin-positive NSCLC had high levels of TMB (t-test performed on log-transformed data). (B) $\beta$-catenin-positive NSCLC tended to have a low expression of PD-L1 (no significant difference by Fisher's exact test between PD-L1-positive and -negative samples). Mean \pm SEM. TMB, tumor mutation burden; PD-L1, programmed death-ligand1; NSCLC, non-small cell lung cancer; TPS, tumor proportion score.

lower PD-L1 TPS compared with $\beta$-catenin-negative NSCLC (Fig. 4B). The median PD-L1 TPS was $0 \%$ (range, $0-20 ; n=7$ ) in the $\beta$-catenin-positive group and $0 \%$ (range, $0-70 ; n=61$ ) in the $\beta$-catenin-negative group.

Whole exome sequencing of CTNNB1 and related genes. Whole exome sequencing showed that three $\beta$-catenin-negative tumors (assessed using immunohistochemistry) had a CTNNB1 mutation. An APC mutation and an AXIN1 mutation were found in one $\beta$-catenin positive tumor each (assessed using immunohistochemistry). No tumors had a TCF7 mutation.

\section{Discussion}

The present study investigated how $\beta$-catenin expression in NSCLC tumors influenced antitumor immune responses. It was found that $\beta$-catenin expression in tumors was negatively associated with TILs in NSCLC, which were associated with the suppression of $\mathrm{CD} 11 \mathrm{c}^{+}$cell recruitment. This result supports the findings of previous reports $(12,13)$. Furthermore, to the best of our knowledge, the present study is the first to reveal that NSCLC-expressing $\beta$-catenin had high TMB, whereas PD-L1 TPS tended to be low. This suggests that NSCLC-expressing $\beta$-catenin might express numerous neo-antigens; however, there were few TILs, and IFN- $\gamma$ production was low in the tumor microenvironment. The MYSTIC trial reported that history of smoking and squamous histology was associated with high TMB; however, PD-L1 expression status was not associated with TMB (33). This data also supports the result in the present study. Lung squamous cell carcinoma was reported to have a high TMB (34) and has a greater association with smoking history compared with lung adenocarcinoma. Therefore, it is likely that smoking history and squamous histology are associated with a high TMB. The present results suggest that IFN- $\gamma$ produced by TILs is associated with PD-L1 expression in NSCLC. This indicates that NSCLC-expressing $\beta$-catenin prevents the cancer immune cycle from progressing, possibly by suppressing lymphocyte infiltration into tumor sites. Furthermore, an immune evasion mechanism might suppress antigen presentation by decreasing APC recruitment (Fig. 5).

Previously, tumors with low immunogenicity, or 'cold' tumors, were thought to have low levels of neo-antigens or have lost the expression of HLA class I. However, Spranger et al (12) used a melanoma model to show that $\beta$-catenin signaling induced the expression of activating transcription factor 3 (ATF3), which suppressed the C-C motif chemokine ligand 4 (CCL4) gene ( $\mathrm{Ccl} 4)$, resulting in the decreased recruitment of $\mathrm{CD} 103^{+}$dendritic cells. Although the production of ATF3 or CCL4 was not examined, tumor evasion might occur by a similar mechanism in NSCLC.

Another finding of the present study was that the expression of $\beta$-catenin was associated with lymphocyte infiltration into tumor nests, but not the total number of TILs in tumor nests or the tumor stroma. In contrast to the present findings, a previous study reported that the number of TILs was associated with the abnormal expression of $\beta$-catenin in NSCLC (19). Even if $\mathrm{CD} 8^{+}$cells are present in the tumor stroma, they may not be able to attack tumor cells, suggesting immune exclusion.

A high number of TILs in NSCLC was reported to be a good prognostic factor $(11,31)$. Although studies have investigated the association between TILs and NSCLC prognosis, whether TILs are present in tumor nests, tumor stroma, or a combination thereof differs between studies. A previous meta-analysis did not determine the site at which TILs can affect the prognosis (35). However, in the current study, TILs in tumor nests were associated with NSCLC prognosis. In a study of colorectal cancer, TILs in the tumor nest, but not the stroma, were associated with prognosis (36), similar to the present findings.

According to the model of Spranger and Gajewski (37), decreased CCL4 secretion in $\beta$-catenin-activated-NSCLC suppressed dendritic cell recruitment, which in turn decreased 


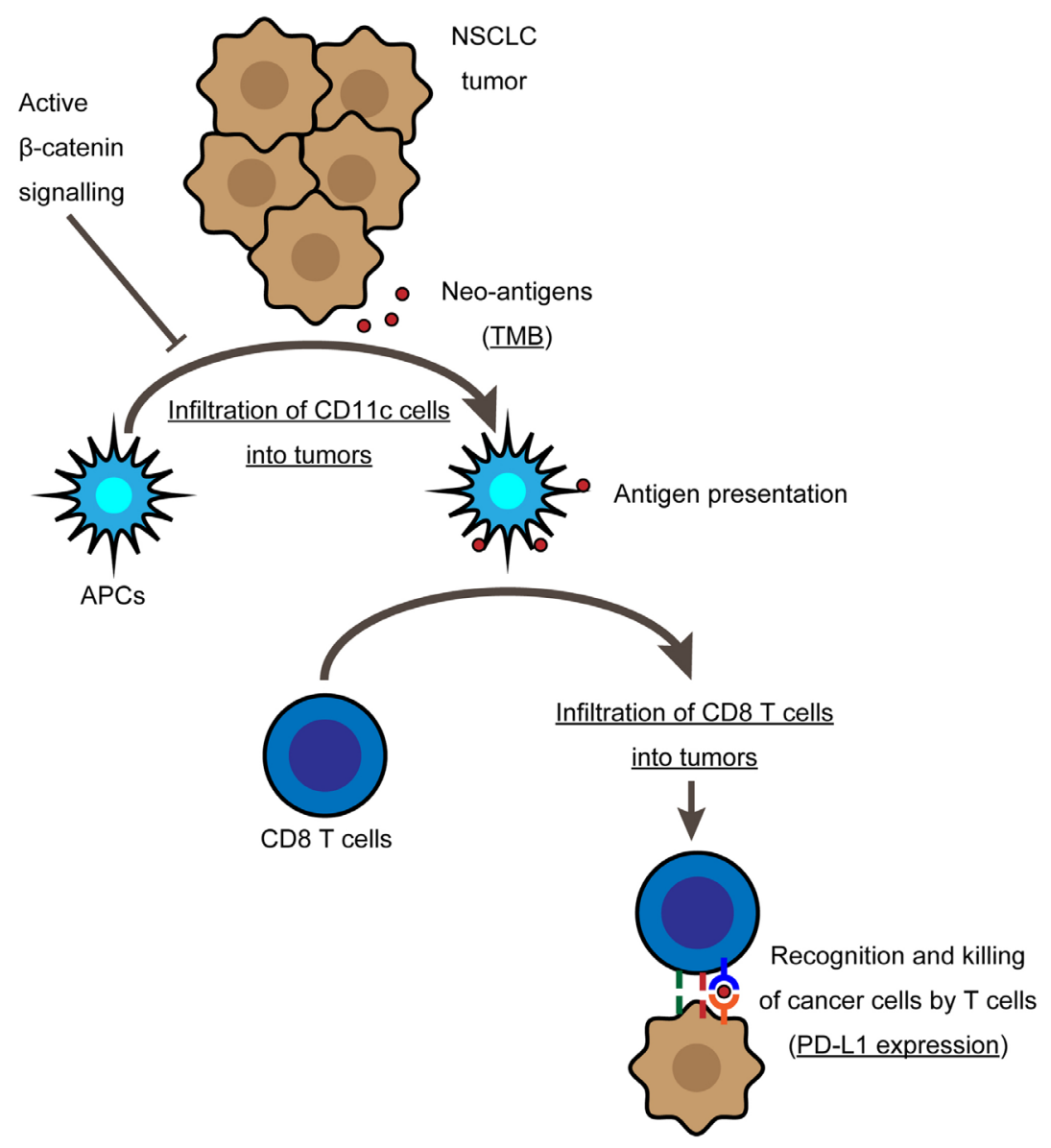

Figure 5. Immune evasion model of $\beta$-catenin-active NSCLC. The infiltration of APCs is suppressed; therefore, lymphocyte infiltration and PD-L1 expression are low, even if the TMB and neo-antigen expression are high. TMB, tumor mutation burden; PD-L1, programmed death-ligand1; NSCLC, non-small cell lung cancer; APC, antigen presenting cells.

the production of C-X-C motif chemokine ligand (CXCL) 9/10 from dendritic cells, preventing lymphocyte infiltration into the tumor microenvironment. The present results are consistent with these findings. It was found that lymphocyte infiltration into tumor epithelium, but not the total number of TILs, was associated with the expression of $\beta$-catenin. This type of lymphocyte infiltration has been termed an "excluded" phenotype (38). Although cytotoxic T lymphocytes are thought to undergo antigen presentation in tertiary lymphoid structures or regional lymph nodes, a second round of $\mathrm{T}$ cell-dendritic cell crosstalk is necessary for T cells to attack tumor cells (39). The activation of $\beta$-catenin and suppression of APC infiltration might suppress this crosstalk. Tumor $\beta$-catenin activation blocks antigen presentation and crosstalk, creating a state of low antigenicity, which explains the remaining low PD-L1 TPS. Therefore, the activation of tumor $\beta$-catenin might be a resistance mechanism of immune checkpoint blockers (37).

Tumor Wnt/ $\beta$-catenin signaling is involved in immune evasion and various carcinogenic and cancer developmental mechanisms including: i) maintenance of a stem cell-like state; ii) activation of EMT; iii) tumor vascularization; and iv) treatment resistance (40). During immune evasion, Wnt ligands released by cancer cells induced canonical and non-canonical Wnt signaling in dendritic cells, resulting in the secretion of the anti-inflammatory cytokine interleukin-10 and indoleamine 2,3-dioxygenase 1 (IDO1), which impaired the ability of dendritic cells to cross-prime cytotoxic T lymphocytes via regulatory $\mathrm{T}$ cells $(41,42)$. A previous study revealed that increased regulatory $\mathrm{T}$ cells were associated with a poor prognosis in NSCLC $(43,44)$.

The role of $\beta$-catenin has been studied in settings other than immune evasion, and $\beta$-catenin has been a drug discovery target for several decades (45). However, in recent years, the activation of $\beta$-catenin has been considered a tumor-cell-intrinsic mechanism of primary and adaptive resistance to immunotherapy via $\mathrm{T}$ cell exclusion, and has therefore attracted increasing attention as a target for drug discovery (40). If $\beta$-catenin inhibitors can turn a 'cold' tumor into a 'hot' tumor (with numerous tumor infiltrating lymphocytes), the effect of immunotherapy might be further enhanced.

In addition to these $\beta$-catenin inhibitors, stimulator of interferon genes (STING) agonists are also attracting attention. STING is a receptor in the endoplasmic reticulum that propagates the innate immune sensing of cytosolic pathogen-derived and self DNA. The STING pathway is critical for IFN- $\beta$ production and dendritic cell cross-presentation $(13,46)$. Therefore, STING agonists provide a therapeutic strategy to initiate endogenous $\mathrm{T}$ cell priming.

The main limitation of the present study was that APCs were not detected by multiple colour immunohistochemistry. CD11c is expressed by dendritic cells and other APCs. The flow cytometry analysis of tumor infiltrating cells revealed that most tumor 
infiltrating blood cells were HLA-DR positive. Most CD11c $\mathrm{c}^{+}$ cells were CD163-positive M2 macrophages, but there were a few CD11c-positive and CD163-negative cells. The CD11c subset contained cells positive and negative for CD14 and CD86. These results indicate that $\mathrm{CD} 11 \mathrm{c}$ was expressed by various type of APCs $(20,21)$. Since only two patients were used for these analyses, the results can only be assumed in this instance.

A second study limitation was that the gene expressions of $\beta$-catenin and ATF3, or CCL4 chemokine production were not examined. The whole exome data indicated mutations in CTNNBI and other associated genes. However, these did not seem to be associated with $\beta$-catenin expression, as assessed by immunohistochemistry. Therefore, the cause of $\beta$-catenin expression was not determined. In addition, other mechanisms associated with $\beta$-catenin-associated cancer types, such as cell proliferation and EMT, were not investigated. Despite these limitations, the present results indicate that $\beta$-catenin activation influences immune evasion by decreasing the recruitment of CD11 $\mathrm{c}^{+}$cells and TILs in NSCLC. The development of novel therapeutic approaches targeting $\beta$-catenin is likely to enhance the immunotherapy of NSCLC.

\section{Acknowledgements}

The authors would like to thank the Biostatistical Consulting Service at the Clinical Research Center, Fukushima Medical University, and in particular Dr Noriko Tanaka, assisted with the interpretation of the results of the statistical analysis. The authors would also like to thank Ms Eiko Ohtomo, Ms Mie Ohtsuki and Ms Yukiko Kikuta (Department of Chest Surgery, Fukushima Medical University, Japan) for their technical assistance.

\section{Funding}

This study was supported by a Grant-in-Aid for Young Scientists (JSPS KAKENHI; grant no. JP19K18222).

\section{Availability of data and materials}

The datasets used and/or analyzed during the current study are available from the corresponding author on reasonable request.

\section{Authors' contributions}

SM and HS designed the study. SM, YO, HY, HM, HT, MW, TIn, TY, MF, NO, YM, TH, JO, MHo, MHi and YS prepared surgically resected samples for the study. SM and YO planned and performed experiments. SM and YO confirm the authenticity of all the raw data. SM, YO, HN, JII, TIs and SW analysed the data. SM and HS wrote the paper.

\section{Ethics approval and consent to participate}

The Human Ethics Committee at Fukushima Medical University approved this study (approval no. 30161). Written informed consent was provided from all participants.

\section{Patient consent for publication}

Not applicable.

\section{Competing interests}

The authors declare that they have no competing interests.

\section{References}

1. Brahmer J, Reckamp KL, Baas P, Crinò L, Eberhardt WEE, Poddubskaya E, Antonia S, Pluzanski A, Vokes EE, Holgado E, et al: Nivolumab versus docetaxel in advanced squamous-cell non-small-cell lung cancer. N Engl J Med 373: 123-135, 2015.

2. Borghaei H, Paz-Ares L, Horn L, Spigel DR, Steins M, Ready NE, Chow LQ, Vokes EE, Felip E, Holgado E, et al: Nivolumab versus docetaxel in advanced nonsquamous non-small-cell lung cancer. N Engl J Med 373: 1627-1639, 2015.

3. Gandhi L, Rodríguez-Abreu D, Gadgeel S, Esteban E, Felip E, De Angelis F, Domine M, Clingan P, Hochmair MJ, Powell SF, et al; KEYNOTE-189 Investigators: Pembrolizumab plus chemotherapy in metastatic non-small-cell lung cancer. N Engl J Med 378: 2078-2092, 2018.

4. Paz-Ares L, Luft A, Vicente D, Tafreshi A, Gümüs M, Mazières J, Hermes B, Çay Şenler F, Csőszi T, Fülöp A, et al; KEYNOTE-407 Investigators: Pembrolizumab plus chemotherapy for squamous non-small-cell lung cancer. N Engl J Med 379: 2040-2051, 2018.

5. Socinski MA, Jotte RM, Cappuzzo F, Orlandi F, Stroyakovskiy D, Nogami N, Rodríguez-Abreu D, Moro-Sibilot D, Thomas CA, Barlesi F, et al; IMpower150 Study Group: Atezolizumab for first-line treatment of metastatic nonsquamous NSCLC. N Engl J Med 378: 2288-2301, 2018.

6. Herbst RS, Soria J-C, Kowanetz M, Fine GD, Hamid O, Gordon MS, Sosman JA, McDermott DF, Powderly JD, Gettinger SN, et al: Predictive correlates of response to the anti-PD-L1 antibody MPDL3280A in cancer patients. Nature 515: 563-567, 2014.

7. Rizvi NA, Hellmann MD, Snyder A, Kvistborg P, Makarov V, Havel JJ, Lee W, Yuan J, Wong P, Ho TS, et al: Cancer immunology. Mutational landscape determines sensitivity to PD-1 blockade in non-small cell lung cancer. Science 348: 124-128, 2015.

8. Tumeh PC, Harview CL, Yearley JH, Shintaku IP, Taylor EJM, Robert L, Chmielowski B, Spasic M, Henry G, Ciobanu V, et al: PD-1 blockade induces responses by inhibiting adaptive immune resistance. Nature 515: 568-571, 2014.

9. Ready N, Hellmann MD, Awad MM, Otterson GA, Gutierrez M, Gainor JF, Borghaei H, Jolivet J, Horn L, Mates M, et al: First-line nivolumab plus ipilimumab in advanced non-small-cell lung cancer (CheckMate 568): Outcomes by programmed death ligand 1 and tumor mutational burden as biomarkers. J Clin Oncol 37: 992-1000, 2019.

10. Blank C, Kuball J, Voelk1 S, Wiendl H, Becker B, Walter B, Majdic O, Gajewski TF, Theobald M, Andreesen R, et al: Blockade of PD-L1 (B7-H1) augments human tumor-specific T cell responses in vitro. Int J Cancer 119: 317-327, 2006.

11. Bremnes RM, Busund L-T, Kilvær TL, Andersen S, Richardsen E, Paulsen EE, Hald S, Khanehkenari MR, Cooper WA, Kao SC, et al: The role of tumor-infiltrating lymphocytes in development, progression, and prognosis of non-small cell lung cancer. J Thorac Oncol 11: 789-800, 2016.

12. Spranger S, Bao R and Gajewski TF: Melanoma-intrinsic $\beta$-catenin signalling prevents anti-tumour immunity. Nature 523: 231-235, 2015.

13. Spranger S, Dai D, Horton B and Gajewski TF: Tumor-residing Batf3 dendritic cells are required for effector $t$ cell trafficking and adoptive t cell therapy. Cancer Cell 31: 711-723.e4, 2017.

14. Rijsewijk F, van Deemter L, Wagenaar E, Sonnenberg A and Nusse R: Transfection of the int-1 mammary oncogene in cuboidal RAC mammary cell line results in morphological transformation and tumorigenicity. EMBO J 6: 127-131, 1987.

15. Yook JI, Li XY, Ota I, Fearon ER and Weiss SJ: Wnt-dependent regulation of the E-cadherin repressor snail. J Biol Chem 280: 11740-11748, 2005.

16. Kim Y, Jin D, Lee BB, Cho EY, Han J, Shim YM, Kim HK and Kim DH: Overexpression of $\beta$-catenin and cyclin D1 is associated with poor overall survival in patients with stage IA-IIA squamous cell lung cancer irrespective of adjuvant chemotherapy. J Thorac Oncol 11: 2193-2201,2016.

17. Wang H, Zhang G, Zhang H, Zhang F, Zhou B, Ning F, Wang HS, Cai SH and Du J: Acquisition of epithelial-mesenchymal transition phenotype and cancer stem cell-like properties in cisplatin-resistant lung cancer cells through AKT/ $\beta$-catenin/Snail signaling pathway. Eur J Pharmacol 723: 156-166, 2014. 
18. Yoo SB, Kim YJ, Kim H, Jin Y, Sun P-L, Jheon S, Lee JS and Chung JH: Alteration of the E-cadherin $/ \beta$-catenin complex predicts poor response to epidermal growth factor receptor-tyrosine kinase inhibitor (EGFR-TKI) treatment. Ann Surg Oncol 20 (Suppl 3): S545-S552, 2013.

19. Ye L, Li H, Wang H, Liu H, Lv T, Zhang F and Song Y: Abnormal $\beta$-catenin expression and reduced tumor-infiltrating T cells are related to poor progression in non-small cell lung cancer. Int J Clin Exp Pathol 10: 11572-11579, 2017.

20. Hogg N, Takacs L, Palmer DG, Selvendran Y and Allen C: The p150,95 molecule is a marker of human mononuclear phagocytes: Comparison with expression of class II molecules. Eur J Immunol 16: 240-248, 1986.

21. Hume DA: Macrophages as APC and the dendritic cell myth. J Immunol 181: 5829-5835, 2008.

22. Malhotra V, Hogg N and Sim RB: Ligand binding by the p150,95 antigen of U937 monocytic cells: Properties in common with complement receptor type 3 (CR3). Eur J Immunol 16: 1117-1123, 1986.

23. Diamond MS, Garcia-Aguilar J, Bickford JK, Corbi AL and Springer TA: The I domain is a major recognition site on the leukocyte integrin Mac-1 (CD11b/CD18) for four distinct adhesion ligands. J Cell Biol 120: 1031-1043, 1993.

24. Blackford J, Reid HW, Pappin DJC, Bowers FS and Wilkinson JM A monoclonal antibody, $3 / 22$, to rabbit CD11c which induces homotypic T cell aggregation: Evidence that ICAM-1 is a ligand for CD11c/CD18. Eur J Immunol 26: 525-531, 1996.

25. Ihanus E, Uotila LM, Toivanen A, Varis M and Gahmberg CG: Red-cell ICAM-4 is a ligand for the monocyte/macrophage integrin CD11c/CD18: Characterization of the binding sites on ICAM-4. Blood 109: 802-810, 2007.

26. Ingalls RR and Golenbock DT: CD11c/CD18, a transmembrane signaling receptor for lipopolysaccharide. J Exp Med 181: $1473-1479,1995$

27. Myones BL, Dalzell JG, Hogg N and Ross GD: Neutrophil and monocyte cell surface p150,95 has iC3b-receptor (CR4) activity resembling CR3. J Clin Invest 82: 640-651, 1988.

28. Loike JD, Sodeik B, Cao L, Leucona S, Weitz JI, Detmers PA, Wright SD and Silverstein SC: CD11c/CD18 on neutrophils recognizes a domain at the $\mathrm{N}$ terminus of the $\mathrm{A}$ alpha chain of fibrinogen. Proc Natl Acad Sci USA 88: 1044-1048, 1991

29. Garnotel R, Rittié L, Poitevin S, Monboisse J-C, Nguyen P, Potron G, Maquart F-X, Randoux A and Gillery P: Human blood monocytes interact with type I collagen through alpha $\mathrm{x}$ beta 2 integrin (CD11c-CD18, gp150-95). J Immunol 164: 5928-5934, 2000.

30. Goldstraw P, Crowley J, Chansky K, Giroux DJ, Groome PA, Rami-Porta R, Postmus PE, Rusch V and Sobin L; International Association for the Study of Lung Cancer International Staging Committee; Participating Institutions: The IASLC Lung Cancer Staging Project: Proposals for the revision of the TNM stage groupings in the forthcoming (seventh) edition of the TNM Classification of malignant tumours. J Thorac Oncol 2: 706-714, 2007.

31. Schalper KA, Brown J, Carvajal-Hausdorf D, McLaughlin J, Velcheti V, Syrigos KN, Herbst RS and Rimm DL: Objective measurement and clinical significance of TILs in non-small cell lung cancer. J Natl Cancer Inst 107: dju435, 2015.

32. Roach C, Zhang N, Corigliano E, Jansson M, Toland G, Ponto G, Dolled-Filhart M, Emancipator K, Stanforth D and Kulangara K: Development of a companion diagnostic PD-L1 immunohistochemistry assay for pembrolizumab therapy in non-small-cel lung cancer. Appl Immunohistochem Mol Morphol 24: 392-397, 2016.
33. Rizvi NA, Cho BC, Reinmuth N, Lee KH, Luft A, Ahn MJ, van den Heuvel MM, Cobo M, Vicente D, Smolin A, et al; MYSTIC Investigators: Durvalumab with or without tremelimumab vs standard chemotherapy in first-line treatment of metastatic non-small cell lung cancer: The MYSTIC Phase 3 randomized clinical trial. JAMA Oncol 6: 661-674, 2020.

34. Schumacher TN and Schreiber RD: Neoantigens in cancer immunotherapy. Science 348: 69-74, 2015.

35. Zeng DQ, Yu YF, Ou QY, Li XY, Zhong RZ, Xie CM and $\mathrm{Hu}$ QG: Prognostic and predictive value of tumor-infiltrating lymphocytes for clinical therapeutic research in patients with non-small cell lung cancer. Oncotarget 7: 13765-13781, 2016.

36. Naito Y, Saito K, Shiiba K, Ohuchi A, Saigenji K, Nagura H and Ohtani $\mathrm{H}: \mathrm{CD}^{+} \mathrm{T}$ cells infiltrated within cancer cell nests as a prognostic factor in human colorectal cancer. Cancer Res 58: 3491-3494, 1998

37. Spranger $\mathrm{S}$ and Gajewski TF: Tumor-intrinsic oncogene pathways mediating immune avoidance. OncoImmunology 5: e1086862, 2015.

38. Galluzzi L, Chan TA, Kroemer G, Wolchok JD and López-Soto A: The hallmarks of successful anticancer immunotherapy. Sci Transl Med 10: 10, 2018.

39. Garris CS, Arlauckas SP, Kohler RH, Trefny MP, Garren S, Piot C, Engblom C, Pfirschke C, Siwicki M, Gungabeesoon J, et al: Successful anti-PD-1 cancer immunotherapy requires $\mathrm{T}$ cell-dendritic cell crosstalk involving the cytokines IFN-gamma and IL-12. Immunity 49: 1148-1161.e7, 2018.

40. Galluzzi L, Spranger S, Fuchs E and López-Soto A: WNT signaling in cancer immunosurveillance. Trends Cell Biol 29: 44-65, 2019.

41. Yaguchi T, Goto Y, Kido K, Mochimaru H, Sakurai T, Tsukamoto N, Kudo-Saito C, Fujita T, Sumimoto H and Kawakami Y: Immune suppression and resistance mediated by constitutive activation of Wnt/ $\beta$-catenin signaling in human melanoma cells. J Immunol 189: 2110-2117, 2012.

42. Holtzhausen A, Zhao F, Evans KS, Tsutsui M, Orabona C, Tyler DS and Hanks BA: Melanoma-derived Wnt5a promotes local dendritic-cell expression of IDO and immunotolerance: Opportunities for pharmacologic enhancement of immunotherapy. Cancer Immunol Res 3: 1082-1095, 2015.

43. Hasegawa T, Suzuki H, Yamaura T, Muto S, Okabe N, Osugi J, Hoshino M, Higuchi M, Ise K and Gotoh M: Prognostic value of peripheral and local forkhead box $\mathrm{P} 3^{+}$regulatory $\mathrm{T}$ cells in patients with non-small-cell lung cancer. Mol Clin Oncol 2: 685-694, 2014

44. Muto S, Owada Y, Inoue T, Watanabe Y, Yamaura T, Fukuhara M, Okabe N, Matsumura Y, Hasegawa T, Osugi J, et al: Clinical significance of expanded Foxp $3^{+}$Helios ${ }^{-}$regulatory $\mathrm{T}$ cells in patients with non-small cell lung cancer. Int J Oncol 47: 2082-2090, 2015

45. Sheridan C: Wnt is back in drugmakers' sights, but is it druggable? Nat Biotechnol 36: 1028-1029, 2018.

46. Woo SR, Fuertes MB, Corrales L, Spranger S, Furdyna MJ, Leung MY, Duggan R, Wang Y, Barber GN, Fitzgerald KA, et al: STING-dependent cytosolic DNA sensing mediates innate immune recognition of immunogenic tumors. Immunity 41 : 830-842, 2014. Erratum in: Immunity 42: 199, 2015.

(i) $(-)$ This work is licensed under a Creative Commons Attribution-NonCommercial-NoDerivatives 4.0 International (CC BY-NC-ND 4.0) License. 